\title{
PENINGKATAN DAYA SAING MELALUI PERBAIKAN PERHITUNGAN HARGA POKOK PRODUKSI INDUSTRI KERIPIK DAN SEJENISNYA
}

\author{
Rasdianto $^{(1)}$, Nurzaimah ${ }^{(2)}$, Mutia Ismail ${ }^{(3)}$ Ricky Ary Syahputra ${ }^{(4)}$ \\ ${ }^{1234}$ Fakultas Ekonomi dan Bisnis Universitas Sumatera Utara
}

\begin{abstract}
Dedication held at Jl. Gaperta, Village Central Helvetia, district of Medan Helvetia, Medan, North Sumatra. Dedication took the title "Increasing Sales Through Improved Calculation of Cost of Production Industry Chips and Peyek". Community service will be made to the two businessmen households of preliminary surveys noting that the two housewives who do it faces constraints in which the products can not be marketed in the modern market or supermarkets because they do not have permission from the Ministry of Health (PIRT) and yet have the certificate Halal and requires few tools left to run the business that has been running for about four years and the effort the other household else has run the business for longer than the others which is about nine years had several employees freelance help in producing products that already have a name of "Kartika" which already has a permit Din Kes port on 215127501152 and already has a certificate from the Halal MUI no; 090100891110 has six types of products namely: cheese potato chips, cheese potato chips, carrot chips cheese, peanut dent, dent dent anchovies and spinach, facing obstacles unavailability of machines to grind boiled carrots and tools to attenuate the dough in bulk for processing production. Service to the community team will strive to help business partners for the constraints that it faces so as to produce a better business. Goal mono community service activities this year is expected to develop a business venture partner that had only done penjulan in traditional markets and by booking with a permit from the Department of Health and halal certificate from MUI venture partner product can be sold in modern markets or in supermarkets and mall- mall that is around the city of Medan and in turn will expand to other cities in North Sumatra.
\end{abstract}

Keywords: $\quad$ Increasing Sales Through Improved Calculation of Cost of Production Industry Chips and Peyek

\section{PENDAHULUAN}

\section{A. Analisis Situasi}

Usaha Mikro adalah usaha produktif milik perorangan dan atau badan usaha perorangan yang memenuhi kriteria usaha mikro sebagaimana diatur dalam Undang-Undang yaitu yang memiliki asset maksimum lima puluh juta rupiah.

Pengertian Usaha kecil menengah dapat dilihat dari beberapa aspek. Dalam perekonomian Indonesia, sector usaha kecil menengah sangat berperan terutama jika dikaitkan dengan jumlah tenaga kerja yang mampu diserap.usaha kecil menengah bergerak dalam beberapa bidang usaha antara lain adalah sktor perrtanian, perdagangan, pertambangan, jasa dan lain sebagainya yang perannya tidak kalah penting dalam menggerakkan roda perekonomian di Indonesia.
Dalam rangka mengaplikasikan tridarma perguruan tinggi beberapa dosen Fakultas Ekonomi dan Bisnis ingin melakukan pengabdian masyarakat pada usaha keripik dan peyek yang dirasa memerlukan pengetahuan mengenai bagaimana cara menentukan harga pokok produksi sehingga harga yang ditetapkan dapat bersaing dengan harga pesaing. Pengabdian pada masyarakat ini akan dilakukan kepada dua orang pengusaha rumah tangga yang dari survey pendahuluan diketahui bahwa kedua ibu rumah tangga yang melakukan usaha ini menghadapi kendala dimana produk yang dihasilkan tidak dapat dipasarkan di pasar modern atau swalayan karena tidak memiliki ijin dari Departemen Kesehatan (PIRT) dan belum memiliki sertifikat Halal serta memerlukan beberapa peralatan lagi untuk menjalankan usaha yang sudah berjalan selama lebih kurang empat tahun terakhir dan usaha rumah tangga yang satunya lagi yang 
Rasdianto. et al. Peningkatan Daya Saing Melalui Perbaikan Perhitungan Harga Pokok Produksi...

sudah menjalankan usahanya lebih lama dari yang lain yaitu sekitar Sembilan tahun terakhir memiliki beberapa orang karyawan lepas yang membantu dalam memproduksi produknya yang sudah memiliki nama yaitu "Kartika" yang sudah memiliki ijin Din Kes PIRT 215127501152 dan sudah memiliki sertifikat Halal dari MUI no; 090100891110 memiliki enam jenis produk yaitu: keripik kentang keju, keripik ubi keju, keripik wortel keju, peyek kacang, peyek teri dan peyek bayam, menghadapi kendala tidak tersedianya mesin untuk menggiling wortel rebus dan alat untuk menipiskan adonan dalam jumlah besar untuk memproses produksinya.

\subsection{Tinjauan Pustaka}

\section{Harga Pokok Produksi}

Menurut (Mulyadi, 1991:5) biaya dalam arti luas merupakan pengorbanan sumber ekonomi, yang diukur dalam satuan uang, yang telah terjadi atau yang kemungkinan akan terjadi untuk tujuan tertentu.

(Ikatan Akuntan Indonesia, 2007:17.94) beban adalah penurunan manfaat ekonomi selama satu periode akuntansi dalam bentuk arus keluar atau berkurangnya aktiva atau terjadinya kewajiban yang mengakibatkan terjadinya penurunan ekuitas yang tidak menyangkut pembagian kepada penanam modal.Seluruh biaya yang menjadi pengorbanan dalam menghasilkan suatu produk jadi berpengaruh terhadap penentuan harga pokok produksi yang dihasilkan.

\section{Unsur - Unsur Harga Pokok Produksi}

Secara umum unsur dari harga pokok produksi dapat dibagi menjadi bahan baku langsung, biaya tenaga kerja langsung dan biaya overhead.

1) Biaya bahan baku langsung (Direct Material Cost)

Biaya bahan baku langsung yaitu biaya yang dikeluarkan untuk memperoleh bahan baku yang digunakan dalam proses untuk memproduksi suatu produk. Oleh karenanya jumlah total biaya bahan baku langsung ini sebanding dengan jumlah unit produk yang dihasilkan atau jumlah volume produksi.
Bahan baku langsung membentuk bagian internal dari produk jadi. Biaya ini meliputi biaya untuk memperoleh bahan baku dan menempatkannya dalam keadaan yang siap diolah.

\section{2) Biaya Tenaga Kerja Langsung (Direct Labor Cost)}

Biaya tenaga kerja langsung merupakan biaya yang dibayarkan kepada tenaga kerja yang ikut secara langsung dapat diidentifikasi kepada suatu produk sebagai obyek biayanya. Seperti halnya bahan baku langsung, biaya tenaga kerja langsung merupakan bagian dari upah atau gaji yang dapat secara khusus dan secara konsisten ditugaskan atau berhubungan dengan proses pembuatan produk, urutan pekerjaan tertentu, hal tersebut dapat dikatakan pula sebagai biaya pekerjaan yang dilakukan oleh para pekerja yang benar benar membuat produk pada lini produksi. Tenaga kerja langsung adalah seluruh karyawan yang secara langsung ikut serta memproduksi produk jadi, yang jasanya dapat diusut secara langsung pada produk, dan upahnya merupakan bagian besar dalam memproduksi produk.Upah tenaga kerja langsung diperlakukan sebagai baiya tenaga kerja langsung serta diperhitungkan langsung sebagai unsur biaya produksi.

\section{3) Biaya Overhead Pabrik}

Dalam perusahaan yang produksinya berdasarkan pesanan, biaya overhead pabrik adalah biaya produksi selain biaya bahan baku dan biaya tenaga kerja langsung. Biaya overhead pabrik juga merupakan komponen biaya produksi yang tidak memiliki hubungan langsung dengan suatu produk tertentu dengan dan tidak diidentifikasi atau ditelusuri kepada produk tersebut dengan cara yang secara ekonomis memungkinkan. Dengan kata lain, biaya produksi tidak langsung ini adalatr biaya yang berkaitan dengan proses produksi diluar biaya bahan baku langsung dan biaya upah langsung.

\section{Harga Jual}

Harga jual merupakan jumlah tertentu yang dibayarkan oleh konsumen terhadap barang atau jasa yang diterima.Harga dapat didefinisikan sebagai jumlah uang yang ditagih untuk suatu produk atau jasa jumlah 
nilai ditukarkan konsumen untuk manfaat memiliki atau menggunakanb arang atauj asa yang diperlukan itu. Harga adalah nilai suatu barang dan jasa diukur dengan sejumlah uang dimana berdasarkan nilai tersebut seseorang atau pengusaha bersedia melepaskan barang dan jasa yang dimiliki kepada pihak lain.

Berikut adalah empat kategori penetapan harga menurut (Boone dan Kurtz, 2002:70).

1) Sasaran profitabilitas

Sebagian besar perusahaan mengejar sejumlah sasaran profitabilitas dalam strategi penetapan harganya.Mereka mengerti bahwa laba merupakan hasil dari pendapatan dikurang beban dimana pendapatan merupakan harg jual dikalikan kuantitas yang terjual.

\section{2) Sasaran volume}

Sasaran volume yang pertama dalam strategi penetapan harga adalah maksimalisasi penjualan (sales maximalization), dan sasaran yang kedua mendasarkan keputusan penetapan harga pada pangsa pasar (market share) yaitu persentase dari sebuah pasar yang dikontrol oleh perusahaan atau produk tertentu.

\section{3) Tingkat kompetisi}

Sasaran penetapan harga ini bertujuan untuk menyamai harga yang ditetapkan pesaing.Dalam banyak bisnis, perusahaan menetapkan harga mereka sendiri untuk menyamakan dengan harga yang telah ditetapkan oleh pemimpin industri dalam hal ini perusahaan yang telah mapan.

\section{4) Sasaran Prestise}

Prestise membuat sebuah harga menjadi relatif tinggi untuk mengembangkan, menjaga citra, kualitas dan eksklusivitas.

Keputusan penetapan harga jual sebuah perusahaan dipengaruhi oleh beberapa faktor, yaitu sebagai berikuit:

\section{Tujuan Pemasaran}

Sebelum menetapkan harga jual, perusahaan seharusnya menentukan strateginya atas produk tersebut, jika perusahaan telah memilih pasar sasarannya dan memposisikanya dengan baik, maka strategi bauran pemasaranya termasuk harga jual akan berjalan dengan baik.

\section{Strategi Bauran Pemasaran}

Harga jual adalah salah satu alat bauran pemasaran yang digunakan perusahaan untuk mencapai tujuan perusahaanya. Keputusan harga jual harus dihubungkan dengan keputusan rancangan pokok, distribusi dan promosi untuk membentuk program pemasaran yang efektif. Keputusan yang dibuat untuk variabel - variabel bauran pemasaran lainnya mempengaruh keputusan harga jual.

\section{Biaya Produksi}

Perusahaan menjadikan biaya sebagai dasar untuk menetapkan harga suatu produk Biaya biaya tersebut termasuk biaya produksi, distribusi, promosi, biaya perpajakan, yang membeban perusahaan.

4. Penentuan harga jual berdasarkan harga pesaing

Semakin tinggi tingkat persaingan harga maka akan semakin sulit bagi perusahaan menetapkan harga yang menguntungkan. Ada beberapa strategi yang dipakai oleh perusahaan untuk menentukan harga jual dan termasuk cara untuk menghadapi harga pesaing. Penentuan harga berdasarkan harga pesaing terbagi menjadi tiga, yaitu:

a. Penentuan harga penetrasi

Penentuan harga penetrasi merupakan penentuan harga suatu produk standar. Metode ini dilakukan dengan cara menetapkan harga awal perdana yang rendah, dengan tujuan agar dapat diterima pasar secara luas. Salah satu tujuan dengan menetapkan tujuan ini adalah mendapatkan loyalitas pelanggan.Keberhasilan penentuan harga penetrasi tergantung pada seberapa besar tanggapan konsumen terhadap penurunan harga.

b. Penentuan harga defensif

Perusahaan menurunkan harga dengan tujuan untuk mempertahankan pasar.Sebagai respon atas penurunan harga produk pesaing.

c. Penentuan harga prastise

Penggunaan harga yang lebih tinggi bagi sebuah produk yang dimaksudkan untuk 
Rasdianto. et al. Peningkatan Daya Saing Melalui Perbaikan Perhitungan Harga Pokok Produksi...

memberikan citra yang mewah.Tujuan dari penetapan harga prastise yaitu untuk memberi kesan lini terbaik bagi produk perusahaan.

\section{Volume Penjualan}

Bagi setiap perusahaan tujuan yang hendak dicapai adalah memaksimumkan profit disamping perusahaan ingin tetap berkembang. Realisasi dari pada tujuan ini adalah melalui-volume penjualan yang mantap karena masalah penjualan merupakan kunci sukses tidaknya suatu perusahaan.

Dalam kegiatan pemasaran kenaikan volume penjualan adalah jumlah dari kegiatan penjualan suatu produk atau jasa yang dihasilkan oleh perusahaan dalam suatu ukuran waktu tertentu.

Adapun faktor-faktor yang mempengaruh volume peniualan menurut (Kotler, 2000:55) antara lain adalah:

\section{a. Harga jual}

Faktor harga jual merupakan hal-hal yang sangat penting dan mempengaruhi penjualan atas barang atau jasa yang dihasilkan.Apakah barang atau jasa yang ditawarkan oleh perusahaan dapat dijangkau oleh konsumen sasaran.

\section{b. Produk}

Produk salah satu faktor yang mempengaruhi tingkat volume penjualan sebagai barang atau jasa yang ditawarkan oleh perusahaan apakah sesuai dengan tingkat kebutuhan para konsumen.

\section{c. Biaya promosi}

Biaya promosi adalah akktivitas-aktivitas sebuah perusahaan yang dirancang untuk memberikan informasi-informasi membujuk pihak lain tentang perusahaan yang bersangkutan dan barang-barang serta jasajasa yang ditawarkan.

\section{d. Saluran distribusi}

Merupakan aktivitas perusahaan untuk menyampaikan dana menyalurkan barang yang ditawarkan oleh perusahaan kepada konsumen yang diujinya.

\section{e. Mutu}

Mutu dan kualitas barang merupakan salah satu faktor yang mempengaruhi volume penjualan. Dengan mutu yang baik maka konsumen akan tetap loyal terhadap produk dari perusahaan tersebut, begitu pula sebaliknya apabila utu produk yang ditawarkan tidak bagus maka konsumen akan berpaling kepada produk lain. Setiap perusahaan memiliki design atau rancang bangun tertentu, akan sangat baik jika sebagian sifat uniknya membedakannya dengan perusahaan lain. Peluang terobosan atau bagian keunggulan bersaing dalam halhal tertentu timbul dari penggunaan kekuatan ini pada saat yang sama dalam design atau rancang bangun.

\subsection{Identifikasi Masalah}

Dari hasil survey pendahuluan yang dilakukan oleh tim ditemukan terdapat beberapa permasalahan yang dihadapi oleh mitra usaha dalam mengembangkan usahanya antara lain adalah tidak memiliki ijin dari Dinas Kesehatan, tidak memiliki setifikat Halal dari MUI, tidak memiliki beberapa peralatan yang dibutuhkan untuk menunjang usaha yang dijalankan dan kurangnya pengetahuan mengenai penentuan harga pokok produksi yang sangat dibutuhkan dalam rangka menentukan harga jual sehingga dapat meningkatkan volume penjualan.

\section{Solusi yang diusulkan}

Untuk mengatasi masalah perijinan dan sertifikat Halal akan diberikan bantuan untuk pengurusan surat-surat dimaksud dan untuk masalah yang berkaitan dengan sarana dan prasarana produksi akan diberikan bantuan berupa mesin penggiling wortel rebus, mesin penipis adonan dan beberapa peralatan yang dibutuhkan lainnya.

\section{TARGET LUARAN}

Sasaran kegiatan pengabdian masyarakat mono tahun ini diharapkan dapat mengembangkan usaha mitra usaha yang tadinya hanya dilakukan penjulan di pasar tradisional dan berdasarkan pesanandengan adanya surat ijin dari Dinas Kesehatan dan sertifikat halal dari MUI produk mitra usaha dapat dijual di pasar modern atau di swalayan dan mall-mall yang ada disekitar kota Medan dan pada gilirannya nanti akan berkembang 
ke kota-kota lainnya di Sumatera Utara. Target luaran yang siqnifikan dari kegiatan pengabdian masyarakat ini adalah :

1. Memperbaiki sistem harga pokok produksi

2. Meningkatkan volume penjualan

3. Meningkatkan kualitas dari produk yang dihasilkan

4. Meningkatkan kepuasan pelanggan

\section{PELAKSANAAN KEGIATAN}

4.1 Khalayak Sasaran Antara yang Strategis. Sasaran kegiatan ini adalah pemilik dan seluruh karyawan Industri Keripik singkongKreasi Lutvi Pancur Batu.Karyawan beriumlah 56 orang. Akan tetapi sewaktu dilaksanakankegiatan pengabdian tidak semua bisa hadir, sehingga hanya 30 orang yang rnengikutikegiatan tersebut. walaupun tidak semua bisa mengikutinya, diharapkan pelatihan yangdilakukan bisa bermanfaat lagi seluruhkaryawan dan pemilik.

\subsection{Keterkaitan.}

Pengabdian ini dilakukan sesuai aplikasi bidang ilmu Akuntansi, juga berdasarkanpertimbangan adanya kemudahan dari pihak manajemen dan seluruh karyawan Industrikeripik Singkong Kreasi Lutvi untuk melaksanakan kegiatan ini.

\subsection{Metode Kegiatan.}

Metode yang dilakukan pada kegiatan ini adalah pelatihan, yang dimulai denganpembukaan oleh anggota pengabdian dan kata sambutan oleh pemilik industri keripiksingkong.Setelah itu, ketua pengabdian melakukan wawancara singkat tentang sistempembukuan yang selama ini disusun oleh pemilik.Kemudian pelatihan dilanjutkan denganmenjelaskanmengenai sistem pembukuan secara sederhana, perhitungan harga pokokproduksidan penentuan harga jual yang dilakukan oleh anggota pengabdian.

\subsection{Rancangan Evaluasi.}

Evaluasi yang dilakukan dalam pelatihan ini adalah evaluasi hasil belajar yangberfokus pada perubahan pengetahuan dan keterampilan dengan memberikan latihan untukmengukur pengetahuan pemilik dan karyawan mengenai materi pelatihan.Sesuai denganpendapat Cascio (2003), bahwa evaluasi hasil belaiar adalah evaluasi pelatihan yangdifokuskan pada perubahan pengetahuan, keterampilan, sikap, perilaku dan motivasi.Menurut Aamodth (2007), evaluasi hasil pelatihan yang berfokus pada perubahanpengetahuan dilakukan sebelum dan sesudah pelatihan dilakukan. Pemilik dan karvawan diberi bahan pelatihan dan disertaitanya jawab, mengenai materi pelatihan.

\section{METODE PELAKSANAAN}

\section{A. Tahapan Survey}

Peninjauan lokasi pengabdian pada mitra usaha peyek dan keripik dan identifikasi kebutuhan peralatan untuk peningkatan produksi peyek dan keripik.

\section{B. Tahapan Pelaksanaan}

Pelaksanaan kegiatan pengabdian diantaranya yaitu dengan pemberian dan penyerahan alat untuk pembuatan adonan beserta alat pemasak. Kemudian pengurusan lebel halal dari MUI dan Ijin dari Dinas Kesehatan.

C. Tahapan Monitoring dan Evaluasi

Kegiatan pendampingan dan evaluasi pasca tahapan pelaksanaan kegiatan pengabdian.

\section{HASIL YANG DICAPAI}

Pengabdian Kepada Masyarakat atas Mitra Usaha pembuatan peyek dan keripik ini telah dilaksanakan sejak bulan September 2016 . Adapun kegiatan-kegiatan yang telah dilakukan adalah sebagai berikut :

1. Sosialisasi akan diadakannya kegiatan pengabdian Kepada Masyarakat atas Mitra Usaha peyek dan keripik tim pengabdian

2. Peninjauan lokasi tempat usaha peyek dan keripik pada kedua mitra pengabdian

3. Peninjauan tempat untuk kegiatan penyuluhan kepada mitra pengabdian

4. Identifikasi alat-alat yang dibutuhkan oleh mitra pengabdian

5. Pengurusan lebel halal dari MUI dan Ijin dari Dinas Kesehatan.

6. Penyuluhan kepada mitra pengabdian tentang produk produk peyek dan keripik

7. Melaksanakan kegiatan penyuluhan pengabdian peyek dan keripik: 
Rasdianto. et al. Peningkatan Daya Saing Melalui Perbaikan Perhitungan Harga Pokok Produksi...
a. Penyuluh untuk motivasi usaha peyek dan keripik
b. Penyuluh harga pokok produksi dan volume penjualan
c. Pemberian alat-alat yang dibutuhkan oleh mitra pengabdian

8. Pemberian surat halal dari MUI dan Ijin dari Dinas Kesehatan

\section{KESIMPULAN DAN SARAN}

Pengabdian Kepada Masyarakat atas usaha peyek dan keripik di Kota Medan telah dapat dijalankan dengan baik dan tanpa halangan yang berarti. Dengan kerjasama tim pengabdian yang baik dan peran aktif dalam kegiatan pengabdian ini maka semuanya telah berjalan sesuai yang diharapkan dan harapannya dapat memberikan manfaat bagi mitra usaha dalam keberlanjutan.

Pengabdian yang kami lakukan ini telah sampai pada tahapan akhir dan untuk selanjutnya kami ingin mitra usaha akan lebih baik lagi dalam usahanya.

\section{DAFTAR PUSTAKA}

Hansen, R. Don, and Marryanne M. Mowen.2005. Management Accounting. Second Edition. Cincinnati, Ohio: SouthWestern Publishing Co.

Carter, Wiliam $\mathrm{K}$ dan Milton F. Usry, 2006. Akuntansi Biaya, Edisi Ketigabelas, Buku I, Penerbit Salemba Empat, Jakarta.

Mulyadi. 2012. Akuntansi Biaya. Yogyakarta: UPP STIM YKPN.

Horngren., Foster, dan Datar, 1987, Cost Accounting: A Managerial Emphasis, yang dialih bahasakan oleh Desi Andhariani, 2005, Akuntansi Biaya: Suatu Pendekatan Manajerial, Erlangga, Jakarta.

Kotler, Philip, 2005. Manajemen Pemasaran, Analisis Perencanaan Implementasi dan Kontrol, Edisi Bahasa Indonesia . Penerbit PT. Prehalllindo, Jakarta.

Mursid, 2008. Manajemen Pemasaran. Penerbit Bumi Aksara. Jakarta

Febrian, Jack. 2003. Menggunakan Internet. Penerbit Informtika, Bandung

International Telecomunication Union. 2010. Data Statistik Penggunaan Internet. Geneva. [http://www.itu.int/ITUD/ict/statistics/2010 ]

Buchari Alma, 2007. Manajemen Pemasaran dan Pemasaran Jasa. Penerbit Alfabeta Bandung http://www.scribd.com/doc/163661207/Penga ruh-Promosi-Dan-Harga-Terhadap-Penjualan 